\title{
A NEW FIND OF A FALCHION FROM CENTRAL POLAND
}

\begin{abstract}
This paper discusses a find of a falchion from the neighbourhood of Gieczno in the Lódzkie Voivodeship. This artefact comes from a sequestration of the collection of an illegal treasure hunter. This $15^{\text {th }}$ century falchion with a conventional blade form stands out with its hilt which is provided with a cap-like pommel, and first of all with a scales rivet which is shaped as an ornamental rosette.
\end{abstract}

Keywords: falchion, Central Poland, Middle Ages, $15^{\text {th }}$ century

Received: 01.06.2020 Revised: 10.09.2020 Accepted: 12.09.2020

Citation: Strzyż P., Skóra K. 2020. A New Find of a Falchion from Central Poland. "Fasciculi Archaeologiae Historicae" 33, 211-215, DOI 10.23858/FAH33.2020.015

Specimens of weaponry find their way to museum collections in many different ways. In recent years in Poland there has been a notable "inflow" of finds which come from confiscations of collections gathered by detectorists. In this way a medieval falchion, together with other weaponry and artefacts of daily use, got into the storeroom of the Łódź-Śródmieście Tax Office. The nature of such finds usually does not allow for a specification of their place of discovery. This is also the case here and all we can say is that this weapon was in all probability found in the neighbourhood of the localities of Gieczno - Modlna - Biała, Zgierz District, Łódzkie Voivodeship.

\section{Description of the artefact and its state of preservation}

The falchion did not survive intact. What is in the worst condition is its single-edged blade, which has no point and is rather strongly corroded through. Its state of preservation does not allow for stating with certainty whether it was provided with a fuller. However, it

\footnotetext{
* Institute of Archaeology, University of Łódź, (D) https://orcid. org/0000-0001-6846-159X; piotr.strzyz@uni.lodz.pl

${ }^{* *}$ Institute of Archaeology and Ethnology, Polish Academy of Sciences, Łódź; (D https:// 0000-0002-3197-6060; kalina.skora@tlen.pl
}

seems that there was no fuller in this case (Fig. 1). On the other hand, the hilt is to a great degree complete what survived was the tang with the pommel and one of the rivets which held the hilt scales. The present total length of the weapon is $377 \mathrm{~mm}$, including c. $242 \mathrm{~mm}$ of the blade length and $135 \mathrm{~mm}$ of the hilt length. The blade slightly tapers toward the point and its maximum width is $37 \mathrm{~mm}$. The blade thickness near the crosspiece is $7 \mathrm{~mm}$, but it can be assumed that it was originally somewhat thicker. The hilt tang is shaped in a trapeze-like way - its maximum width is $33 \mathrm{~mm}$ near the pommel and $25 \mathrm{~mm}$ near the blade. It is concave on one side and flat on the other side. Such a shape facilitated the piercing of rivet openings. ${ }^{1}$ Three such openings can be found in the discussed artefact. The opening next to the blade is $7 \times 6 \mathrm{~mm}$. The second opening is somewhat larger as it measures $9 \mathrm{~mm}$. A complete rosette-like rivet with a diameter of $13 \mathrm{~mm}$ survived in the position nearest to the pommel. Its length is $24 \mathrm{~mm}$ and it probably marks the original thickness of the hilt with the scales. The pommel is low in the shape of a cap composed of a few layers of metal sheets. These are adjusted to the

\footnotetext{
${ }^{1}$ Marek 2008, 47; Ławrynowicz and Rychter 2012, 257; Žákovský 2014, 259-260, Figs. 212-214.
} 

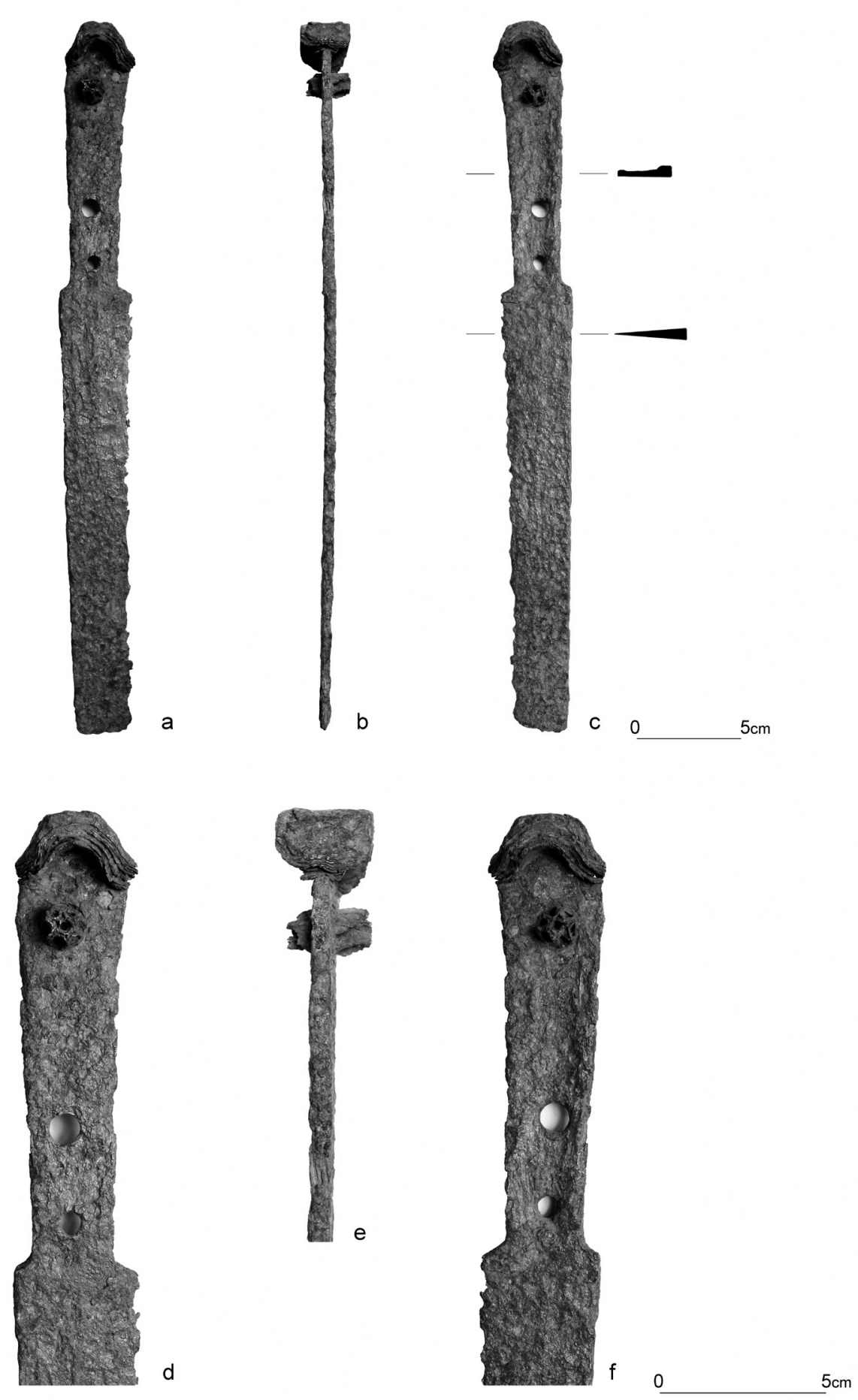

Fig.1. Falchion from the neighbourhood of Gieczno. Photo J. Słomska.

semicircular shape of the tang and are riveted on it. The pommel's dimensions are $37 \times 27 \mathrm{~mm}$ and its height is $10 \mathrm{~mm}$ (Fig. 1). An opening for the properly shaped hilt tang goes through the entire length of the pommel. The pommel fits the tang tightly and no traces of hammering the tang for the purpose of riveting were noticed. No hand guard survived on the falchion in question. There is no opening for a protective guard that would be placed at the contact point of the blade and the hilt. However, what may have been present was a short crosspiece which was only put onto the blade and it did not require additional fastening. ${ }^{2}$ On the other hand, it is equally probable that a side guard was attached in the smallest of the openings (Fig. 2:a-b). Regrettably, this is a mere supposition. The weight of the falchion in the present state of preservation is $322 \mathrm{~g}$.

${ }^{2}$ A crosspiece that is prepared in such a way can be seen, e.g. on a falchion which was found in the Town Hall in Koło, Koło District, see Gorczyca 2012, 200, Figs. 2-5. 


\section{Typological and chronological analysis}

The shape and the proportions of the blade of the artefact in question enable it to be rather classified as Type II according to M. Głosek and L. Marek. This is first of all evidenced by an almost parallel course of the edge in relation to the back of the blade, as well as by a small fault which separates the blade from the tang. Regrettably, as in the case of Type I falchions, the shape of the blade does not allow for a more precise assessment of the artefact's chronology. This form was in use throughout the entire $15^{\text {th }}$ century. ${ }^{3}$

The next component - the pommel - is remarkable for its cap-like shape. Due to this, it can be considered Type B according to L. Marek ${ }^{4}$ and P. Žákovský. ${ }^{5}$ Their characteristic trait is the presence of metal spangles which could be used in order to exactly fit the pommel to the hilt scales with no risk of damage to the latter. ${ }^{6}$ Quite often iron spangles were interlaid with brass or bronze ones, thus achieving an additional ornamentation motif. ${ }^{7}$

Cap-like pommels of Type B (together with a similar Type A) are fairly popular among falchions which are found in the territory of Poland. It is possibly to mention, among others, two hilts from Rogowiec Castle, Wałbrzych District, and an almost complete find from Wrocław-Poświętne. ${ }^{8}$ An identical hilt can also be seen on an artefact from Czersk, stored in the Polish Army Museum in Warsaw. ${ }^{9}$ P. Žákovský assumes that finds from the Czech Republic, including Moravia, which are provided with various forms of low, cap-like pommels can be dated to the $15^{\text {th }}$ century. These artefacts include, e.g. finds from Bruntál, Bruntál District, Lovčičky, Vyškov District, Přerov, Přerov District, Staré Město, Uherské Hradiště District, or Starý Jičín, Nový Jičín District. ${ }^{10}$ As regards finds with more precise chronology, it is possible to mention hilt fragments from Rokštejn Castle, Ihlava District, most probably from the $1^{\text {st }}$ half of the $15^{\text {th }}$ century, ${ }^{11}$ as well as from the knightly residence in Mstěnice, Třebíč District, which can be dated to before $1468 .{ }^{12}$

With regard to the construction of the discussed falchion from the neighbourhood of Gieczno, special attention is drawn to the rosette-like rivet which

${ }^{3}$ Głosek 1990, 123; Marek 2008, 49.

${ }^{4}$ Marek 2008, 63-64.

5 Žákovský 2014, 287-291, Figs. 243-244, 286.

${ }^{6}$ Marek 2008, 54; see also Žákovský et al. 2013, 129.

${ }^{7}$ See Žákovský et al. 2013, Fig. 5.

${ }^{8}$ Marek 2008, 53-54, 156-157, Figs. 51:a, 52:a and 54:b-c.

${ }^{9}$ Nadolski 1978, 39, cat. no.102, Tab. 24; Głosek 1990, Fig. 14.

${ }^{10}$ Žákovský 2014, cat. nos. 27, 91, 195, 224, 226.

${ }^{11}$ Krejsová 2007, 268-270, Fig. 2:1-2; Měřínský 2007, 110, Fig. 62:1,11; see also Žákovský et al. 2013, 112.

${ }^{12}$ Nekuda 1985, 139, 141, Fig. 196:a; Žákovský et al. 2013, 110-111, Figs. 1:m and 5:c; Žákovský 2014, cat. no. 103. survived in the tang of the hilt. So far, no analogies have been found to it among artefacts which were published in Poland. What is significant, however, is the fact that such rosettes which are usually made from non-ferrous metal are one of typical construction parts of so-called falchions of Moravian type. In such weapons these rivets can usually be seen on pommels. A falchion from Gorzów Śląski, Olesno District is one of weapons which was ornamented in this way (with two rosettes). This artefact was classified as the socalled falchion of Moravian type and it is dated to the $1^{\text {st }}$ half of the $15^{\text {th }}$ century. ${ }^{13}$ Such a motif can also be seen on the pommel that was found in the course of examinations of the knightly tower in Witków. It is dated to the $1^{\text {st }}$ half of the $15^{\text {th }}$ century. ${ }^{14}$ Furthermore, the pommel of the falchion from the locality of Poręba Wielka, Limanowa District, is provided with as many as four rosettes. This weapon stands out with its long double-edged blade. ${ }^{15}$ This group also encompasses the most recent discovery from Kostrzyn nad Odrą, Gorzów Wielkopolski District. This find is also dated to the $15^{\text {th }}$ century. ${ }^{16}$

This way of ornamentation was also applied in falchions with so-called high pommels from the territory of the Czech Republic, just to mention finds from Mstěnice, Třebíč District, Odry, Nový Jičín District, Opava, Opava District, or Vracov, Hodonín District. ${ }^{17}$ Pommels with such traits are also known from the territory of Slovakia, e.g. Gajary near Bratislava, which is dated to before $1467,{ }^{18}$ or from Graz in Austria $\left(15^{\text {th }}\right.$ century). ${ }^{19}$

What co-occurred with high pommels of Moravian type falchions were remarkable "boat-like" crosspieces. In their Variant $4 \mathrm{~b}$ according to P. Žákovský, the terminals are "filled" with the same rosettes as those in pommels. ${ }^{20}$ Concerning such finds, it is possible to mention, e.g. the aforementioned artefact from Gorzów Śląski, ${ }^{21}$ the weapon from Aueršperk, Žd'ár on the Sázava River District, ${ }^{22}$ unprovenanced specimens from the Deutsches

\footnotetext{
${ }^{13}$ Marek 2006, 197, Fig. 5:a; Marek 2008, 57, Fig. 61:a-c.

${ }^{14}$ Marek and Michalak 2008, 453, Figs. 3, 4:a-d and 5:b.

15 Głosek 1992, 35-36, Figs. 1 and 2; Glinianowicz 2005, 156,
} Tab. X:2.

${ }^{16}$ Michalak and Socha 2019, 143-145, Figs. 2 and 3:1-4.

${ }^{17}$ Nekuda 1985, Figs. 196:b and 197:e-f; Ž́ákovský 2012, $724-$

725, Figs. 7:d, 12:a-d, 15:a-b, 19:d, 22:b and 24:b-d; Žákovský 2014, 306-307, Figs. 259:a-b, d-e and 260:a-d; cat. nos. 108, 180, $184,264-265$.

${ }^{18}$ Polla 1962, 117, Figs. 5:5, 18:11; Žákovský 2012, 721,

Fig. 12:e; Ž́ákovský 2014, Figs. 259:g and 260:e.

${ }_{19}$ Marek 2008, Fig. 75:a.

20 Žákovský 2014, 352.

${ }^{21}$ Marek 2006, 197, Fig. 5:a; Marek 2008, 57, Fig. 61:a-b.

22 Žákovský 2012, 698-700, 721-722, Figs. 6:d, 24:g; Ž́kovský 2014, 352, Fig. 307:a, cat. no. 1. 

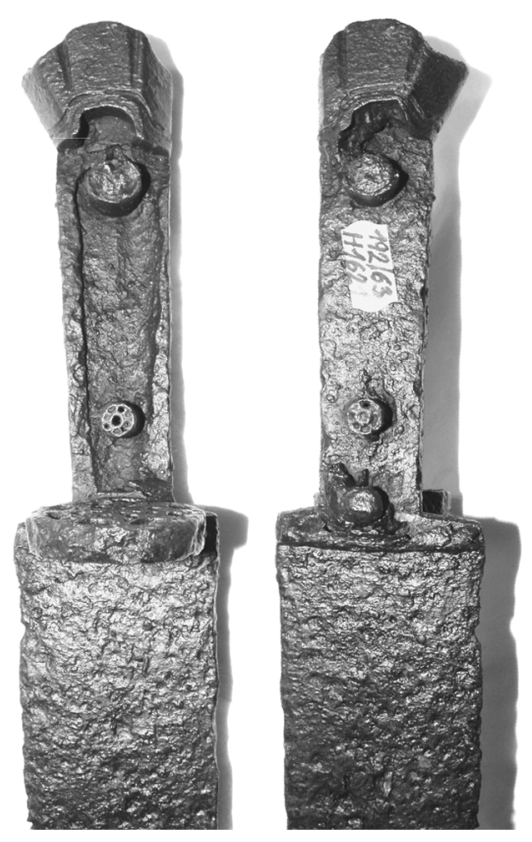

a
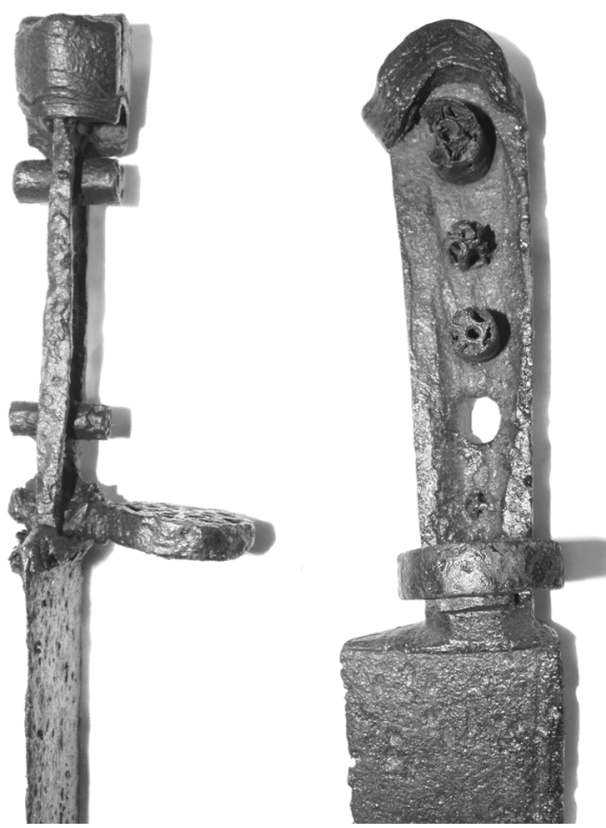

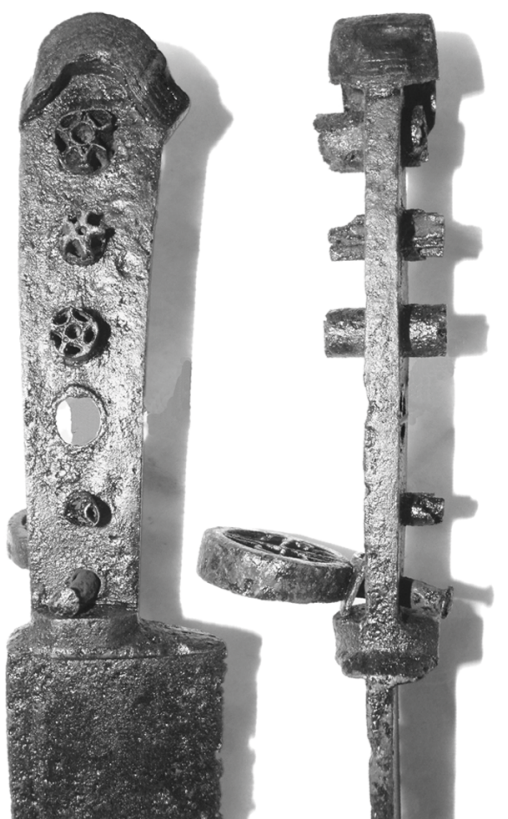

b

Fig. 2. Falchions from Moravia with hilt rivets in the shape of rosettes: a - Bruntál Museum; b-Vysočina Museum in Jihlavá. After Žákovský 2011, Figs. 2 and 3.

Historisches Museum in Berlin, and perhaps the weapon from the Polish Army Museum in Warszawa. ${ }^{23}$

Some falchions are also provided with small openwork guards which protect the hand. Examples of such finds are known, e.g. from the localities of Bludov, Šumperk District, Loučka-Hradiště, Vsetín District, Př́kazy, Olomouc District or Východná-Zámčisko near Liptovský Mikuláš in Slovakia. The presence of this weapon part which is shaped in such a way allows to refine the chronology of artefacts which were provided with them and date such weapons to the $2^{\text {nd }}$ half of the $15^{\text {th }}$-early $16^{\text {th }}$ century. ${ }^{24}$

From a formal point of view, the artefact which is the most similar to the discussed falchion is the find of unknown provenance stored in the Museum in Bruntál. Its hilt is provided with a cap-like pommel and with rosette-like rivets on the tang of its hilt. Its protective guard is shaped as an openwork rosette. This artefact is dated to the end of the $15^{\text {th }}$ century ${ }^{25}$ (Fig. 2:a). Yet another falchion, also of unknown provenance, is stored in the collection of the Bohemian-Moravian Highlands Museum in Jihlava. Its hilt is provided with three rosette-like rivets, its pommel is composed of spangles and is fitted to the scales. The weapon is provided with

\footnotetext{
${ }^{23}$ Žákovský 2012, 699-700, Fig. 6:a, c, with further literature there.

${ }^{24}$ See Žákovský 2011, 511-512, Fig. 5:a; Žákovský 2014, cat. nos. 3, 87, 201.

${ }_{25}$ Žákovský 2011, 503, Figs. 1:a, 2, 4:a, 5:a, 6:a, 7:a; Žákovský 2014, cat. no. 132.
}

an openwork protective guard (Fig. 2:b). This artefact is dated to the $2^{\text {nd }}$ half of the $15^{\text {th }}$ century. ${ }^{26}$ Moreover, a rosette-like rivet with a diameter of $15 \mathrm{~mm}$ can also be seen on the falchion from Mstěnice, provided with a Type B pommel. The appearance of the hilt of the find from Nový hrad near Kunratice is similar. ${ }^{27}$ In this place it must also be said that the falchion hilt from Rogowiec Castle is provided with an ornament in the form of brass tubes forming the shape of small rosettes. ${ }^{28}$ As rightfully stressed by P. Žákovský, falchions with such rivets are relatively rare now. This, however, results from the state of preservation of finds, as in many cases rivets of this kind simply fell off. ${ }^{29}$ The discussed weapon from the neighbourhood of Gieczno may have also been provided with one more rivet of this kind. This is implied by a large central opening in the tang.

The falchion from the neighbourhood of Gieczno completes a short list of finds of weapons of this kind from the territory of Central Poland. It is difficult to relate this discovery to specific military actions in this region in the Middle Ages. Broad-scale hostilities are not recorded in written sources. Therefore, the owner lost the falchion in other circumstances, which are

\footnotetext{
${ }^{26}$ Žákovský 2011，503，Figs. 1:b，3，4:b，5:b，6:b，7:b; Žákovský 2014, cat. no. 139.

${ }^{27}$ See Nekuda 1985, Fig. 196:a; Žákovský et al. 2013, 110-

111, Figs. 1:m, 5:c; Žákovský 2014, 269, Fig. 224, cat. no. 103.

${ }^{28}$ Marek 2008, 53, Fig. 51:a.

29 Žákovský 2011, 509.
} 
difficult to assess. The present state of preservation of this artefact is quite far from its original appearance. Due to this, the aforementioned analogies only allow for a rather general assessment of the time of its origin as the $15^{\text {th }}$ century. It is worth noting that in nearby Gieczno in the $14^{\text {th }}$-the $1^{\text {st }}$ half of $15^{\text {th }}$ century there was a knightly residence, belonging to the Toporczyk family. Initially, it was a place that was fortified only by a rampart with a palisade, but in the second phase of its use it was expanded into a motte-and-bailey timber castle. ${ }^{30}$ According to preliminary arrangements, after necessary procedures this weapon will be handed to the Museum in Zgierz. Thus, the collection of this museum will be enriched with an interesting example of late medieval cold steel.

\section{Bibliography}

Glinianowicz M. 2005. Stan badań nad uzbrojeniem późnośredniowiecznym w Małopolsce. “Acta Militaria Mediaevalia" 1, 143-164.

Głosek M. 1990. Broń biała dtuga. In: A. Nadolski (ed.), Uzbrojenie w Polsce średniowiecznej 1350-1450. Łódź, 111-124.

Głosek M. 1992. Interesujacy zabytek broni biatej z Poręby Wielkiej. "Rocznik Sądecki” 20, 35-40.

Gorczyca K. 2012. Kord z ratusza w Kole. In: I. Skierska (ed.), Królewskie miasto Koło. Studia w 650. rocznice lokacji miasta. Koło, 195-213.

Krejsová J. 2007. Dochované fragmenty tesáki̊ z hradu Rokštejna. "Archeologické výzkumy na Vysočině” 1, 266-276.

Ławrynowicz O., Rychter M. 2012. Ile wart jest kord z Warty. "Acta Militaria Mediaevalia" 8, 253-271.

Marek L. 2006. Średniowieczne i nowożytne kordy ze Śląska. "Acta Militaria Mediaevalia" 2, 189-206.

Marek L. 2008. Broń biała na Ślasku XIV-XVI wiek. Wratislavia Antiqua 10.Wrocław.

Marek L., Michalak A. 2008. Głowica kordu z wieży rycerskiej w Witkowie. In: B. Gruszka (ed.), Ad Oderam fluvium. Księga dedykowana pamięci Edwarda Dąbrowskiego. Zielona Góra, 449-467.

Měřínský Z. 2007. Hrad Rokštejn. Déjiny, stavebni vývoj a výsledky čtvrtstoletí archeologického výzkumu 19812006. Brtnice, Brno.

Michalak A., Socha K. 2019. Late Medieval Weaponry Finds from Kostrzyn nad Odra. Cultural and Historical Context. "Acta Militaria Mediaevalia" 14, 137-151.

Nadolski A. (ed.) 1978. Broń średniowieczna z ziem polskich. Warszawa.

Nekuda V. 1985. Mstěnice 1. Zaniklá středověká ves u Hrotovic. Hrádek-tvrz-dvưr-předsunutá opevnění. Brno.

Nierychlewska A., Sikora J. 2018. Późnośredniowieczna ceramika naczyniowa z gródka stożkowatego w Giecznie, gm. Zgierz, pow. zgierski, woj. łódzkie. "Acta Universitatis Lodziensis. Folia Archaeologica" 33, 113-151.

Polla B. 1962. Pamiatky hmotnej kultúry 15. storočia z Posádky pri Gajaroch. "Sbornik Slovenského Národného Múzea" 46, História 2, 107-140.

Žákovský P. 2011. Tesáky s prořezavánými záštitnými trny z moravských zbírek. “Archeologické rozhledy” 53(3), 501-516.

Žákovský P. 2012. Tesáky s člunkovitými záštitami a jejich postaveni ve vývoji chladných zbrani. "Archaeologia historica" 37(2), 691-732.

Žákovský P. 2014. Tesáky a problematika jednosečných zbrani středověku a raného novověku. Katalog (mps. dizertační práce, Filozofická fakulta Masarykovy univerzity, Ústav archeologie a muzeologie, Brno / PhD typespript in the autor's archive).

Žákovský P., Hošek J., Bárta P. 2013. Dussacks with Broad Blades and a Probable Method of Their Manufacturing. In: L. Marek (ed.), Weapons Bring Peace? Warfare in Medieval and Early Modern Europe. Wratislavia Antiqua 18. Wrocław, 105-136.

${ }^{30}$ Nierychlewska and Sikora 2018, 118-119, 143-146, Figs. 1-3. 